\title{
George F. Kennan a „sprawa polska” u schyłku II wojny światowej
}

\begin{abstract}
Wolałbym, abyśmy zamiast słów pełnych optymizmu wykazali zrozumienie i dobry smak, chyląc w ciszy głowy nad tragedią narodu [polskiego - P.K.], który jest naszym sprzymierzeńcem, któremu pomogliśmy ocalić się przed naszym wspólnym wrogiem, lecz którego nie możemy uchronić przed naszymi przyjaciółmi.
\end{abstract}

George Kennan, sierpień 1944 r.

George Kennan jest człowiekiem zasad.

Isaiah Berlin

Za przedmiot analizy obrałem ogląd „sprawy polskiej” — sytuacji i działań Polaków w okupowanej Polsce, sytuacji rządu RP na wychodźstwie, planów Stalina wobec Polski - dokonywany w ostatnich dwóch latach II wojny światowej przez George'a F. Kennana. Kennan w powojennym świecie to jedna z najważniejszych figur amerykańskiego życia politycznego i intelektualnego, „ojciec polityki powstrzymywania”. Ściśle rzecz biorąc, amerykański dyplomata stał się sławą po napisaniu tzw. Dlugiego telegramu oraz opublikowaniu na jego podstawie artykułu Sources of Soviet Conduct ${ }^{1}$. W kwietniu 1947 r., na prośbę ówczesnego amerykańskiego sekretarza stanu George'a Marshalla, Kennan powołał Policy Planning Staff — działający przez wiele lat przy Departamencie Stanu think tank.

Marshall polegał w bardzo dużym stopniu na radach Kennana przy formułowaniu amerykańskiej polityki zagranicznej. W rzeczy samej, Kennan odgrywał

1 Por. X [G.F. Kennan], The Sources of Soviet Conduct, „Foreign Affairs”, lipiec 1947. 
zasadniczą rolę przy tworzeniu planu Marsalla, jak również Radia Wolna Europa oraz dyrektoriatu tajnych operacji CIA ${ }^{2}$.

Warto jednocześnie odnotować, że autor American Diplomacy był także wysokiej klasy myślicielem strategicznym oraz filozofem politycznym ${ }^{3}$. Miał talent do zadawania zasadniczych pytań. Jak wyraził się inny ważny amerykański dyplomata - Paul Nitze:

George Kennan nauczył nas patrzenia na kwestie polityczne z szerszej perspektywy, uwzględniającej kulturę $\mathrm{i}$ interesy innych graczy, także naszych oponentów, a nie wyłącznie z perspektywy wąsko pojętych, bieżących interesów Stanów Zjednoczonych ${ }^{4}$.

Autor Democracy and the Student Left odważnie poszukiwał teoretycznych fundamentów amerykańskiej polityki, by objaśniać sposoby jej działania w przeszłości i poszukiwać jej udoskonaleń na przyszłość. Poszukiwania te były doceniane przez amerykańskich czytelników. Dość powiedzieć, że Kennan dwukrotnie otrzymał Nagrodę Pulitzera oraz National Book Awards i Bancroft Prize za Russia Leaves the War.

W krótkim przypomnieniu sylwetki Kennana nie sposób pominąć jego kasandrycznych uzdolnień. Przykładowo, na samym początku zimnej wojny przewidział, jak się ona zakończy. Pojął również natychmiast, że podział Niemiec i utworzenie NATO utrwali podział Europy. Już w 1949 r. był świadom, w jaki sposób rozwijać się będzie nuklearny wyścig zbrojeń. Przewidział pęknięcie chińsko-radzieckie i bardzo wcześnie dostrzegł słabe punkty amerykańskiej strategii w Wietnamie ${ }^{5}$. Był także przenikliwym krytykiem ostatniej amerykańskiej interwencji w Iraku. Zatem w kilku przynajmniej momentach swego życia zaprzeczył ludzkiej niemocy myślowej wobec przyszłości. W odniesieniu do amerykańskiego myśliciela chciałoby się nieraz powiedzieć to, co Bronisław Łagowski rzekł o Hermannie Rauschningu:

Nie mając wystarczającej wiedzy, człowiek nie posiada też — jeśli nie liczyć poetów — ani ułamka tej zdolności przeczuwania zagrożeń, jaką w stosunku do nadciągających katastrof naturalnych wykazują niekiedy zwierzęta. Toteż nie błędnym przewidywaniom powinniśmy się dziwić. Prawdziwie zastanawiające są raczej owe rzadkie umysły przenikliwie odczytujące przyszłość w rzeczywistości już dokonanej i w pozornym czy rzeczywistym chaosie zmian dostrzegające główny kierunek ruchu ${ }^{6}$.

2 J. Mearsheimer, Introduction, [w:] G.F. Kennan, American Diplomacy: Sixtieth-Anniversary Expanded Edition, Chicago 2012, s. VII. Tłumaczenia cytatów anglojęzycznych - P.K.

${ }^{3}$ Fragment jego konserwatywnej filozofii politycznej dotyczącej stosunku do natury i cywilizacji przemysłowej zaprezentowałem w tekście Ecological Threads in George F. Kennan's Political Thought, „Ecology and Safety. Journal of International Scientific Publications” 10, 2017.

${ }^{4}$ Cyt. za: N. Thompson, The Hawk and the Dove: Paul Nitze, George Kennan, and the History of the Cold War, New York 2009, s. 2.

5 Por. ibidem, s. 4.

6 B. Łagowski, Rauschning i jego rewolucja nihilizmu, [w:] idem, Co jest lepsze od prawdy?, Kraków 1986, s. 118. 
Udane prognozy co do przyszłości nie oznaczają bynajmniej, że Kennan pozostawał nieomylny. Przyjmując punkt widzenia politycznego realizmu, trudno się z nim zgodzić, że w pierwszej połowie XX w. Stany Zjednoczone uprawiały liberalną — tzn. legalistyczną i moralizatorską — politykę zagraniczną, odżegnując się od polityki opartej na sile. W przekonaniu amerykańskiego dyplomaty Stany Zjednoczone i generalnie demokracje liberalne zachowywały się w niebezpiecznym świecie polityki zagranicznej — ku swojej szkodzie — odmiennie aniżeli reżimy innego typu. To naturalnie wielce kontrowersyjna i trudna do obrony teza.

W połowie 1944 r., kiedy Kennan ponownie przybył do Moskwy, był jeszcze dyplomatą drugiego rzędu. Jego obecności na placówce zażądał amerykański ambasador w ZSRR William Averell Harriman. Kennan słusznie uchodził bowiem za jednego z najlepszych - obok Charlesa E. Bohlena - ekspertów od Rosji. Rzecz jasna fakt, że nie jest on postacią pierwszoplanową, wpływa na ilość informacji, jakie posiada, na ilość spraw, do których jest dopuszczany i proszony w ich sprawie o konsultację. Jednak, jak się okazuje, brak pełni informacji nie wpływa w istotny sposób na zadziwiającą niekiedy trafność i przenikliwość uwag formułowanych przez autora American Diplomacy.

Zdaniem omawianego autora Rosja sowiecka jest, zgodnie z wielowiekową tradycją, państwem o charakterze ekspansjonistycznym, nieskorym do zwracania raz poczynionych nabytków. Czyż nie jest w tym względzie symptomatyczny fakt, że Stalin nawet w stanie najwyższego zagrożenia, po ataku Hitlera na ZSRR, zgadzając się w rozmowach z Brytyjczykami, że pakt Ribbentrop-Mołotow przestał obowiązywać, nie zgodził się na restytucję państwa polskiego po zakończeniu wojny w granicach z 1939 r. Nie zgodził się na oddanie ziem zagarniętych na mocy układu z III Rzeszą. Co ciekawe, interpretacja Kennana paktu Ribbentrop-Mołotow nie jest, jak generalnie w przypadku Polaków, wyłącznie moralistyczna, lecz także polityczna. Znajdujemy u niego bowiem sugestię, że przynajmniej jedna z układających się stron była niejako w swoim prawie, zawierając umowę, która odwlekała w czasie nieuchronną wojnę między sygnatariuszami tejże umowy. Była w prawie na mocy powszechnie obowiązującej polityczno-strategicznej zasady, że należy dążyć do jak najpóźniejszego przystępowania do wojny i że generalnie wojnę wygrywa ten, komu udaje się wejść do niej na końcu i zachować najwięcej sił.

\footnotetext{
Monachium — znamionujące ziszczenie się koszmaru odosobnionej wojny niemiecko-rosyjskiej — ostatecznie rozwiało nadzieję [rządzących Rosją sowiecką — P.K.] na walkę Zachodu z Hitlerem z innych powodów aniżeli wyłącznie we własnej samoobronie [...]. Tym samym otworzyła się [przed Rosją — P.K.] przestrzeń dla polityki otwartej ekspansji terytorialnej, prowadzonej, jeśli to możliwe, w celu zapobieżenia [niemieckiemu - P.K.] atakowi na Rosję lub w celu złagodzenie tego ataku, gdyby do niego doszło ${ }^{7}$.
}

7 G.F. Kennan, Russia - Seven Years Later, [w:] idem, Memoirs: 1925-1950, Boston 1967, s. 519 . 
W Kennanowskiej analizie perspektyw dla Polski i możliwości ułożenia się rządu londyńskiego ze Stalinem u schyłku II wojny pakt Ribbentrop-Mołotow — „największa bomba w długich dziejach dyplomacji europejskiej” — odgrywa zasadniczą rolę. Nie tylko wyrażał on ekspansjonistyczny charakter polityki Moskwy nakierowanej na

ponowne ustanowienie rosyjskiej władzy w Finlandii i państwach bałtyckich, wschodniej Polsce, w północnej Bukowinie oraz w Besarabii. Dążył do ustanowienia kurateli nad zachodnią Polską i zdobycia przez imperium rosyjskie dostępu do Morza [Bałtyckiego - P.K.] gdzieś w Prusach Wschodnich. Oznaczał zdobycie dominującego wpływu nad wszystkimi Słowianami w Europie Centralnej i na Bałkanach i, jeśli to możliwe, stworzenie korytarza pomiędzy Słowianami zachodnimi a południowymi, biegnącego gdzieś wzdłuż granicy austriacko-węgierskiej $^{9}$.

Pakt Ribbentrop-Mołotow umożliwił przede wszystkim Stalinowi dokonanie na opanowanych przez siebie ziemiach polskich zbrodni w latach 1939-1941. Wywiezienie w głąb Rosji w nieludzkich warunkach ponad miliona polskich obywateli ${ }^{10}$ oraz wymordowanie polskich oficerów w Katyniu. Zbrodnie te ostatecznie przesądzały, zdaniem Kennana, o niemożliwości ustanowienia w Polsce jakiegokolwiek rządu, który w jakimkolwiek stopniu byłby samodzielny. Jedynym możliwym rozwiązaniem był całkowicie uzależniony od Moskwy rząd komunistyczny. Tym samym kwestia odzyskania przez Polaków własnego państwa jawiła się Kennanowi jako beznadziejna, nie mówiąc już o sytuacji polskiego rządu w Londynie.

Tuż przed swoim ponownym przybyciem do Moskwy w 1944 r. Kennan odbył rozmowę z radcą polskiej ambasady w Waszyngtonie Janem Wszelakim, która doprowadziła go do przedstawionego wniosku. W swoich Pamiętnikach Kennan zanotował:

Wyszedłem z tej dyskusji [z Janem Wszelakim - P.K.] z silnym poczuciem, że wrogie działania Stalina wobec rządu polskiego na uchodźstwie, choć bez wątpienia po części po prostu powodowane poprawą sytuacji militarnej i politycznej Rosji, nie dają się w pełni wytłumaczyć inaczej aniżeli w kategoriach głębokiego wstydu po stronie sowieckiej z uwagi na okrucieństwa popełnione w stosunku do Polaków w latach 1939-1940 przez sowiecką policję polityczną i wynikające stąd postanowienie, że nie może istnieć po wojnie rząd [polski — P.K.] skłaniający się czy też posiadający zdolności do niewygodnego wnikania w przeszłość i robienia sprawy publicznej z działań władz sowieckich. Oznaczało to, o ile mój tok myślenia był poprawny, że sprawy rządu polskiego na uchodźstwie przedstawiały się znacznie gorzej niźli zachodnie rządy skłonne były uważać w tamtym czasie [...]. Stalinowi nie chodziło — jak zakładało wielu naszych ludzi — o to, by mieć „przyjazny rząd” za swoją zachodnią granicą. Dla niego istotne było posiadanie każdego przyszłego rządu współpracującego z nim w ukry-

${ }^{8}$ G. Mann, Niemieckie dzieje w XIX i XX wieku, przeł. A. Kopacki, Olsztyn 2007, s. 496.

9 G.F. Kennan, Memoirs: 1925-1950..., s. 519.

10 Jak wiadomo, ok. 50\% spośród wywiezionych nie przeżyła wywózki. Jedną z najbardziej przejmujących relacji z owej tragedii Polaków pozostaje praca J. Czapski, Na nieludzkiej ziemi, Kraków 2001. 
waniu dowodów i zacieraniu pamięci o działaniach policji sowieckiej w okresie 1939-1941, dla których nigdy nie będzie zadowalającego i przyzwoitego wytłumaczenia. Było jasne, że polski rząd, który oferowałby tego typu współpracę, może być tylko rządem komunistycznym pod ścisłą sowiecką kontrolą ${ }^{11}$.

Jest rzeczą zastanawiającą, że Kennan, który często zarzuca swoim rodakom naiwność w myśleniu o Rosji, sam również — przynajmniej po części — w tę naiwność popada. Jakkolwiek przerażające i oburzające może to się zdawać, zsowietyzowanie ziem zagarniętych przez ZSRR we wrześniu 1939 r. mogło udać się tylko po usunięciu stamtąd - tzn. wywiezieniu bądź fizycznej eliminacji — wykształconej, kulturowo rozbudzonej części „żywiołu” polskiego. Stalin realizował więc sowiecką rację stanu, naturalnie w sposób charakterystyczny dla totalitarnego systemu, który stworzył. Jeżeli jednak stworzył i stwarzał wciąż na nowo piekło swoim własnym obywatelom ${ }^{12}$, z jakiego powodu miał szczególnymi względami obdarzać i po rycersku traktować Polaków? Skoro zatem mamy do czynienia z realizacją na totalitarną modłę — bez cofania się przed najbardziej okrutną inżynierią społeczną - sowieckiej racji stanu, bardzo trudno, a nawet kuriozalnie byłoby psychologizować i doszukiwać się u Stalina „głębokiego wstydu" po dokonaniu gwałtów na polskiej ludności, o którym pisze Kennan. Oczywiście nie ulega wątpliwości, że podnoszenie na forum międzynarodowym kwestii mordów popełnionych na polskich obywatelach czy walka propagandowa z ZSRR prowadzona przez niezależny polski rząd mogłyby stanowić dla Stalina pewien problem. Nie można jednak się łudzić co do tego, że Stalin i każdy następny przywódca sowiecki konsekwentnie zaprzeczałby katyńskiemu mordowi i obarczał winą Niemców, co przecież znajduje potwierdzenie w faktach. Złudzeniem byłoby także sądzić, że w tej walce propagandowej leżąca po polskiej stronie racja rozstrzygałaby z łatwością jej wynik i kierowała opinię publiczną świata przeciw Sowietom. Stanisław Cat-Mackiewicz przytomnie notował, że propaganda, nawet najlepsza, nie zastąpi siły politycznej i że „Stalin będzie miał zawsze lepszą od nas propagandę, bo ma pięćset dywizji" "13. Stany Zjednoczone nie grały kartą katyńską w całym okresie zimnej wojny, choć przecież była to znakomita sposobność do zohydzenia przeciwnika. Może było tak dlatego, że już w trakcie wojny amerykańskie władze wiedziały o tej zbrodni. Nic w tej sprawie nie zrobiły, bo potrzebowały owych 500 dywizji Stalina. Później było już na to za późno.

Dla Kennana sprawa polska stanowi swoisty papierek lakmusowy ukazujący intencje ZSRR, odpowiadający na pytanie, czy Rosja sowiecka chce prowadzić uczciwą, ludzką i nakierowaną na współpracę politykę w Europie. Innymi słowy,

11 G.F. Kennan, Memoirs: 1925-1950..., s. 203.

12 Przejmująco sowieckie pandemonium przedstawia O. Figes, Szepty: życie w stalinowskiej Rosji, przeł. W. Jeżewski, Warszawa 2008.

13 S. Cat-Mackiewicz, Lady Makbet myje ręce. Broszury emigracyjne 1944-1946, Kraków 2014. 
to stosunek Stalina do Polski miał ostatecznie przesądzić, czy Stany Zjednoczone popełniły błąd i obsadziły ZSRR w roli stałego sojusznika, zamiast obsadzić go w roli sojusznika tymczasowego i kierować do niego pomoc skrojoną na miarę właśnie sojusznika tymczasowego, nie stałego.

Trzeba przyznać, że Kennan w 1944 r. nie miał już praktycznie wątpliwości, że Rosję sowiecką należy traktować jako sojusznika tymczasowego, którego po wojnie - ze względu na jej ekspansjonizm — będzie trzeba powstrzymywać. W przekonaniu tym utwierdzało go wiele posunięć Stalina w odniesieniu do rządu polskiego w Londynie, powołanie Polskiego Komitetu Wyzwolenia Narodowego, a przede wszystkim stosunek władz sowieckich do Powstania Warszawskiego. Jeśli zatrzymanie ofensywy sowieckich wojsk i przyglądanie się rzezi powstańców nie było dostatecznym probierzem intencji Stalina, to — w oczach Kennana było nim nieudzielenie zgody na wykorzystanie amerykańskiej bazy znajdującej się na Ukrainie w celu dokonania zrzutów broni i zaopatrzenia dla powstańców. Co więcej, władze sowieckie zażądały całkowitej likwidacji tejże bazy.

Kennan nie był obecny na spotkaniu ze Stalinem i Wiaczesławem Mołotowem, które odbył ambasador Harriman w asyście generała Johna Russella Deane’a. Usłyszał jednak od nich bezpośrednią relację tuż po spotkaniu. Przekaz strony sowieckiej był, wedle relacji zasłyszanej przez Kennana od Harrimana i Deane'a, następujący:

Zamierzamy opanować Polskę w całości. Guzik nas obchodzą polscy żołnierze podziemia nieakceptujący władzy komunistycznej. Dla nas nie są oni lepsi od Niemców i jeśli oni i Niemcy wyrżną się nawzajem, tym lepiej. Nie obchodzi nas, co wy, Amerykanie, myślicie o tym wszystkim. Od teraz nie będziecie mieć udziału w kształtowaniu spraw w Polsce i czas najwyższy, żebyście to sobie uświadomili ${ }^{14}$.

Zdaniem Kennana był to odpowiedni moment na spojrzenie przez Zachód prawdzie w oczy, jeśli chodzi o intencje ZSRR i jego dalsze możliwości współpracy z Zachodem. Była to właściwa chwila, by skonfrontować się z przywódcami sowieckimi i dać im wybór pomiędzy

całkowitą zmianą ich polityki i zgodą na ustanowienie prawdziwie niepodległych krajów w Europie Wschodniej a wycofaniem poparcia i pomocy Zachodu na pozostałe fazy wojny. Nie byliśmy im już dłużej nic dłużni (o ile kiedykolwiek byliśmy). Drugi front został utworzony. Zachodni alianci posiadali swoje siły zbrojne na kontynencie europejskim. Terytorium sowieckie było całkowicie wyzwolone. Sowieckie działania wojenne związane były teraz wyłącznie z przyszłością terytoriów niesowieckich uprzednio opanowanych przez Niemców. My, ludzie Zachodu, mieliśmy pełne prawo uwolnić się od odpowiedzialności za dalsze sowieckie działania wojenne prowadzone w duchu odmowy wsparcia Powstania Warszawskiego z wszelkimi tego implikacjami ${ }^{15}$.

Widać, chociażby w cytowanej, doniosłej wypowiedzi, że Kennan-człowiek zasad bierze górę nad Kennanem-dyplomatą i politykiem. Dla niego Powstanie

14 G.F. Kennan, Memoirs: 1925-1950..., s. 211.

15 Ibidem. 
Warszawskie jest tym momentem, w którym w wielkiej grze politycznej kończą się możliwości relatywizowania zagadnień i należy zakrzyknąć za Lutrem: przy tym stoję i nie mogę inaczej.

Sprawy nie doszły jednak do tego punktu w oczach Franklina D. Roosevelta i Winstona Churchilla. Czyż maestria tych polityków Zachodu nie polegała koniec końców na tym, by pobić III Rzeszę rękami czerwonoarmistów zamiast rękami chłopców z Londynu czy Waszyngtonu? Czyż w imię ratowania niepodległego państwa polskiego oraz ratowania powstańców warszawskich mieli skazywać na śmiertelne zapasy z wermachtem swoich własnych obywateli zamiast nieznanych im Rosjan, Ukraińców, Białorusinów i Polaków? Ich konflikt na tym etapie z ZSRR, odcięcie Rosjan od dostaw w ramach Land-Lease Act, co Kennan proponował, oznaczałby bez wątpienia konieczność zaangażowania znacznie większych sił anglosaskich. Trudno oczywiście podawać w wątpliwość, że Stalin rozumiał grę przywódców Zachodu. Godził się na dźwiganie zasadniczego ciężaru wojny, ponieważ wiedział, że po jej zakończeniu wystawi Zachodowi rachunek w postaci konieczności przyzwolenia na opanowanie Europy Środkowo-Wschodniej.

Nie może dziwić, że Kennan, jasno uświadamiając sobie sytuację Polski i Polaków, z zażenowaniem przyjmował spotkania odbywane z Mikołajczykiem $i$ jego otoczeniem w ambasadzie brytyjskiej i amerykańskiej, gdy przylecieli oni do Moskwy na negocjacje ze Stalinem pod koniec lipca 1944 r. Sprawa polska coraz bardziej przypominała mu pozorowaną grę, której wynik już dawno został ustalony. Nie tylko w owym tragicznym okresie negocjacji Stalin-Mikołajczyk oraz w trakcie Powstania Warszawskiego, ale także gdy później, wiosną 1945 r. służył jako tłumacz ambasadorowi Harrimanowi podczas długich, odrealnionych dyskusji z Mołotowem i Andriejem Wyszyńskim nad kandydaturami Polaków spoza komunistycznego obozu, którzy mogliby znaleźć się w koalicyjnym rządzie polskim. Rozmowy na ten temat odbywały się na mocy postanowień konferencji w Jałcie. Uczestniczył w nich sowiecki minister spraw zagranicznych Mołotow oraz amerykański i brytyjski ambasador. Poczucie surrealizmu Kennana w trakcie tych rozmów byłoby jeszcze intensywniejsze, gdyby, jak sam notuje:

wiedział, że podczas naszych rozmów władze sowieckie aresztowały po cichu za naszymi plecami niektórych spośród Polaków, o których dyskutowaliśmy, wywierając na nich presję, by zostali sowieckimi agentami, o czym w ogóle nie wiedzieliśmy ${ }^{16}$.

W kontekście sprawy polskiej Kennan dokonuje również przenikliwej i wczesnej interpretacji zamiarów władz ZSRR w związku z przesunięciem przyszłej granicy polsko-niemieckiej mocno na zachód. Po artykule Stefana Jędrychowskiego - kierownika resortu informacji i propagandy PKWN - w „Prawdzie" na temat przyszłego kształtu zachodniej granicy Polski, na sześć tygodni przed dyskusją o Polsce na konferencji w Jałcie, Kennan napisał memorandum,

16 Ibidem, s. 212. 
w którym realistycznie oceniał przyczyny i skutki przesunięcia terytorium państwa polskiego na zachód. Jego zdaniem Rosjanie doskonale zdawali sobie sprawę, że

im dalej na zachód i w głąb Niemiec sięgać będzie zachodnia granica Polski, tym większa będzie ekonomiczna i militarna zależność Polaków od Związku Sowieckiego [...]. Wiedzą oni [Rosjanie - P.K.], że ustanowienie linii Odry jako granicy Niemiec musi z konieczności sprawić, że żaden polski rząd na wschód od tej linii nie będzie niczym więcej niż władzą lokalną, a polskie terytorium na mocy żelaznej logiki wypadków stanowić będzie wojskową, ekonomiczną i polityczną odpowiedzialność Związku Sowieckiego. [...] Ma to głębokie implikacje. Czyni nierealistyczną ideę istnienia wolnej i niezależnej Polski. Ustanawia granicę w Europie Środkowej, którą można utrzymać wyłącznie za cenę permanentnej obecności na całej jej długości potężnych sił zbrojnych. [...] Prawdopodobnie nie będziemy w stanie zapobiec realizacji tego projektu. Sądzę jednak, że bylibyśmy na bakier z realizmem, gdybyśmy nie zdołali rozeznać, czemu on służy, i nie nadali mu odpowiedniej rangi w naszym myśleniu o przyszłości Europy ${ }^{17}$.

Wydaje się, że Kennanowi precyzyjnie udało się prześwietlić sowieckie racje stojące za przesunięciem Polski na zachód. Racją tą nie jest Powstanie Warszawskie, jak niedawno usiłował dowodzić Andrzej Nowak:

Właśnie w trakcie powstania Stalin ustalił, że trzeba dać Polakom jak najwięcej ziem na zachodzie. Nie dało się dłużej podtrzymać propagandowej tezy Stalina, że Polska (ta związana $\mathrm{z}$ tradycją II RP) stoi tylko z bronią u nogi i na żadną rekompensatę za zabór dokonany na wschodzie przez Stalina nie zasługuje ${ }^{18}$.

Po pierwsze, to, że Polacy chcą się bić i biją się wyśmienicie z Niemcami pod warunkiem że są podobnie jak przeciwnik uzbrojeni i wyszkoleni — pokazał przed powstańcami warszawskimi II Korpus generała Władysława Andersa. Po drugie, i ważniejsze, zachodnia granica Polski została ustalona przez wielką trójkę w zasadniczych kształtach na konferencji w Teheranie 28 listopada-1 grudnia 1943 r., zatem osiem miesięcy przed wybuchem Powstania Warszawskiego. Nieokreślony pozostawał południowy odcinek granicy polsko-niemieckiej, tzn. nie było jasne, czy ma on biec wzdłuż Nysy Łużyckiej czy Kłodzkiej ${ }^{19}$. Powstanie Warszawskie nie miało z wyznaczeniem tej granicy żadnego związku. Militarnie wymierzone było w Niemców, ale politycznie w Stalina, z czego sowiecki dyktator doskonale zdawał sobie sprawę. Za wymierzone w siebie powstanie miał nagradzać Polaków przekazaniem 104 tys. $\mathrm{km}^{2}$ ziem należących przed wojną do Niemiec?

W toku niekończących się w Polsce dyskusji nad Powstaniem Warszawskim wiele było jego zadziwiających uzasadnień i usprawiedliwień wysuwanych przez

17 Ibidem, s. 214.

18 Żałosny mit realizmu. Z prof. Andrzejem Nowakiem rozmawia Marcin Makowski, „Do Rzeczy. Tygodnik Lisieckiego", 18-23.04.2017, s. 70.

19 Por. H. Feis, Churchill, Roosevelt, Stalin. The War They Waged and the Peace They Sought, Princeton 1957, s. 287. 
obóz politycznych romantyków. Wśród nich znajdowały się m.in. takie, że gdyby nie powstańcy warszawscy, ZSRR zajęłoby całe Niemcy, a tak — dzięki powstańczemu heroizmowi - Niemcy Zachodnie po wojnie były wolne, nie zaś komunistyczne. Oznacza to ni mniej, ni więcej, że polscy powstańcy i ludność cywilna umierali na ulicach Warszawy za wolność mieszkańców Bonn, Kolonii, Stuttgartu itp.

Interpretacja Nowaka także zajmuje bardzo wysoki szczebel na drabinie zdziwień, jeśli chodzi o korzyści płynące z powstania. Ta interpretacja jest wszakże ważna o tyle, że ujawnia bardzo częste w Polsce i charakterystyczne dla politycznego romantyzmu niezrozumienie kategorii siły w polityce. Zakłada, mówiąc najprościej, że słabi potrafią powodować silnymi, narzucać im rozwiązania, zmuszać do prowadzenia określonej przez siebie polityki — tak jak w ujęciu Nowaka powstańcy warszawscy zmusili Stalina do podarowania Polakom ziem zachodnich. Słabi mogą narzucić silnym kierunek działania tylko przez przypadek. Gdyby w historii tak się zdarzało, że silni pozwalaliby słabym — najczęściej sojusznikom — na definiowanie swoich poczynań, popełnialiby jeden z najkarygodniejszych błędów politycznych. Błędów, za które trzeba byłoby potem słono płacić życiem własnych obywateli. Stalin nie był kimś, kto by nie rozumiał tego punktu elementarza polityki.

\section{Bibliografia}

Cat-Mackiewicz S., Lady Makbet myje ręce. Broszury emigracyjne 1944-1946, Kraków 2014.

Czapski J., Na nieludzkiej ziemi, Kraków 2001.

Feis H., Churchill, Roosevelt, Stalin. The War They Waged and the Peace They Sought, Princeton 1957.

Figes O., Szepty: życie w stalinowskiej Rosji, przeł. W. Jeżewski, Warszawa 2008.

Gaddis J.L., George F. Kennan: an American Life, New York 2011.

Kennan G.F., American Diplomacy: Sixtieth-Anniversary Expanded Edition, Chicago 2012.

Kennan G.F., Memoirs: 1925-1950, Boston 1967.

Kennan G.F., Russia - Seven Years Later, [w:] idem, Memoirs: 1925-1950, Boston 1967.

Kennan G.F., The Sources of Soviet Conduct, „Foreign Affairs”, July 1947.

Kimla P., Ecological Threads in George F. Kennan's Political Thought, „Ecology and Safety. Journal of International Scientific Publications" 10, 2017.

Łagowski B., Rauschning i jego rewolucja nihilizmu, [w:] idem, Co jest lepsze od prawdy?, Kraków 1986.

Mann G., Niemieckie dzieje w XIX i XX wieku, przeł. A. Kopacki, Olsztyn 2007.

Mearsheimer J., Introduction, [w:] G.F. Kennan, American Diplomacy: Sixtieth-Anniversary Expanded Edition, Chicago 2012.

Thompson N., The Hawk and the Dove: Paul Nitze, George Kennan, and the History of the Cold War, New York 2009.

Żałosny mit realizmu. Z prof. Andrzejem Nowakiem rozmawia Marcin Makowski, „Do Rzeczy. Tygodnik Lisieckiego", 18-23.04.2017. 
GEORGE F. KENNAN AND THE “POLISH CAUSE” AT THE END OF WORLD WAR II

\section{Summary}

The article aims at explaining why the famous American diplomatist and intriguing political thinker George F. Kennan already in 1944 considered "the Polish cause" as the "all a lost cause" and did not believe in the possibility of restitution of Poland as an independent country after World War II. According to Kennan, this was determined primarily by the Russo-German Nonaggression Pact signed in August 1939. Strictly speaking, by the crimes committed on the Polish population by the Soviet police authorities in 1939-1941. Another important factor was the general expansionist nature of the Soviet regime. Even the Warsaw uprising filled with the unprecedented heroism could not change anything in Stalin's policy towards Poland.

Keywords: George F. Kennan, Russo-German Nonagression Pact, Warsaw uprising, Polish government in-exile, Stalin, Soviet policy towards Poland, American Policy towards Poland, American embassy in Moscow.

Piotr Kimla

piotr.kimla@uj.edu.pl 